\title{
Financial Statements Are About To Get A New Look
}

Clemense Ehoff Jr., Kean University, USA

\begin{abstract}
In October 2008, The FASB and the IASB issued a discussion letter for comment proposing a complete redesign of financial statements. This was the result of a project that began for both boards in 2001. More than 200 comment letters were received from individuals, accounting firms, professional societies, corporations, and others from the business community. The FASB and $I A S B$ have analyzed the input, and are currently preparing an exposure draft scheduled for release in early 2011. This paper reviews the proposed changes to the financial statements, summarizes the favorable and unfavorable responses contained in the comment letters, and examines the implications that the changes will have on the business community, the accounting profession, educators, and investors.
\end{abstract}

Keywords: Financial Statements; Comment letters; FASB; IASB

\section{INTRODUCTION}

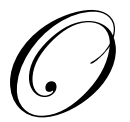

n October 16, 2008, the Financial Accounting Standards Board (FASB) and the International Accounting Standards Board (IASB) issued a discussion paper "Preliminary Views on Financial Statement Presentation," the result of a project that began for both boards in 2001. The paper sought public comment, to be used as input in the development of an exposure draft. The comment period ended on April 14, 2009. 227 comment letters were received from individuals, accounting firms, professional societies, corporations, academics, and others from the business community. A comment letter summary was presented at the July 14, 2009 IASB/FASB meeting. In July 2010, the IASB and the FASB posted a draft of the Exposure Draft, a working document that expresses the current and tentative decision made so far on this project.

The changes to financial statement presentation proposed by the IASB and FASB are far reaching and will have an enormous impact on the entire business community. This paper reviews the proposed changes to the financial statements, summarizes the favorable and unfavorable responses contained in the comment letters, and examines the implications that the changes will have on the business community, the accounting profession, educators, and investors.

\section{THE DISCUSSION PAPER}

The October 16, 2008 Discussion Paper (Preliminary Views, 2008) was the result of a project that began in 2001. In undertaking the financial statements presentation project, the FASB and IASB 's intention was to establish a new standard for presenting information in the financial statements. In doing so, they set a goal of improving the usefulness of financial statement information to help users make more informed decisions as capital providers. Three broad objectives for financial statement presentation were developed:

1. Cohesiveness: There is a clear relationship between items across financial statements.

2. Disaggregation of Information: Financial information should be disaggregated into reasonably homogenous groups of items so that it is useful in predicting an entity's future cash flows.

3. Liquidity and Flexibility: Liquidity information helps users asses the entity's ability to meet financial commitments as they become due. Information flexibility helps users assess the entity's ability to invest in opportunities and react to unexpected situations. 
The proposed financial statement model divides the statement of financial position (balance sheet), the income statement, and the statement of cash flows into two sections: business activities, and financing activities. The business section is further subdivided into operating activities and investing activities. The financing section describes how the entity's business activities are financed, segregating owner and non-owner sources. Discontinued operations are shown separately from the entity's business and financing activities. Income taxes are shown separately in the statement of financial position and the statement of cash flows. In the income statement, income tax information is shown separately for 1) income from continuing operations, 2) discontinued operations, and 3) other comprehensive income items. Table 1 illustrates the proposed classification scheme.

Table 1: Proposed Financial Statement Classification

\begin{tabular}{|c|c|c|}
\hline Statement of Financial Position & Statement of Comprehensive Income & Statement of Cash Flows \\
\hline $\begin{array}{cl}\text { Business } & \\
\bullet & \text { Operating assets and liabilities } \\
\bullet & \text { Investing assets and liabilities }\end{array}$ & $\begin{array}{cl}\text { Business } & \\
\bullet & \text { Operating income and expenses } \\
\text { - } & \text { Investment income and expenses }\end{array}$ & $\begin{array}{c}\text { Business } \\
\text { - Operating cash flows } \\
\text { - } \quad \text { Investing cash flows }\end{array}$ \\
\hline $\begin{aligned} & \text { Financing } \\
& \text { - } \text { Financing assets } \\
& \text { - } \text { Financing liabilities }\end{aligned}$ & $\begin{array}{l}\text { Financing } \\
\bullet \quad \text { Financing asset income }\end{array}$ & $\begin{array}{ll}\text { Financing } \\
\text { - } & \text { Financing asset cash flows } \\
\text { - } & \text { Financing liability cash } \\
& \text { flows } \\
\end{array}$ \\
\hline Income taxes & $\begin{array}{l}\text { Income taxes on continuing operations } \\
\text { (business and financing) }\end{array}$ & Income taxes \\
\hline Discontinued operations & Discontinued operations net of tax & Discontinued operations \\
\hline & Other comprehensive income, net of tax & \\
\hline Equity & & Equity \\
\hline
\end{tabular}

Note: Adapted from Discussion Paper (Preliminary Views, 2008).

This structure is substantially different from the current financial statement structure as shown in Table 2:

Table 2: Current Financial Statement Classification

\begin{tabular}{|c|c|c|}
\hline Balance Sheet & Income Statement & $\begin{array}{l}\text { Statement of Cash Flows } \\
\text { (Direct or Indirect Method) }\end{array}$ \\
\hline $\begin{aligned} \text { Assets } & \\
\text { - } & \text { Current Assets } \\
\text { - } & \text { Property, Plant \& Equipment } \\
\text { - } & \text { Other Assets }\end{aligned}$ & $\begin{array}{cl}\text { Operating Income } \\
\text { - } & \text { Sales } \\
\text { - } & \text { Cost of Goods Sold } \\
\text { - } & \text { Gross Profit } \\
\text { - } & \text { Operation Expenses } \\
\text { - } & \text { Operating Income }\end{array}$ & $\begin{array}{cl}\text { Operating Activities } \\
\qquad \quad \text { Operating cash flows } \\
\text { - Investing cash flows }\end{array}$ \\
\hline $\begin{array}{ll}\text { Liabilities } \\
\text { - } \\
\text { - } & \text { Long-term Liabilities } \\
& \text { Lonilities }\end{array}$ & $\begin{aligned} \text { Other } & \\
\bullet & \text { Other Revenue } \\
\bullet & \text { Other Expense }\end{aligned}$ & Investing Activities \\
\hline \multirow[t]{4}{*}{ Equity } & $\begin{array}{ll}\text { Continuing Operations } \\
\text { - Income Before Taxes } \\
\text { - Income Taxes } \\
\text { - Income from Continuing } \\
\quad \text { Operations }\end{array}$ & Financing Activities \\
\hline & Discontinued operations net of tax & Change in Cash \\
\hline & Extraordinary Item (net of tax) & \\
\hline & Net Income & \\
\hline
\end{tabular}

Note: Adapted from Intermediate Accounting ( $6^{\text {th }}$ ed.) by D. Spiceland, J. Sepe, \& M. Nelson. New York: McGraw-Hill Irwin. (2011). 
In comparing these structures, several significant changes are noticed:

1. Assets and liabilities are still divided into current and long-term categories, but are further divided into business (and divided again into operating and investing components) and financing categories.

2. In the new Statement of Financial Position, subtotals for current assets, current liabilities, total assets and total liabilities have been included and placed at the bottom of the statement.

3. The new Statement of Income goes beyond traditional Net Income and includes components of other comprehensive income in arriving at total comprehensive income.

4. The new Statement of Income does not contain a separate line item for extraordinary items.

5. The new Statement of Cash Flows must use the direct method.

The fourth statement in the proposed model is the statement of changes in equity. The structure proposed for this statement resembles a reconciliation of beginning balances, ending balances, and how each amount changed during the period. Each component of equity is presented in the statement. Currently, a reconciliation of only Retained Earnings (or Owners' Equity) is shown.

The statement of financial position, the income statement, the statement of cash flows, and the statement of changes in equity comprise a complete set of financial statements. Samples of each financial statement are presented in the Appendix.

There are several additional important aspects of the proposed presentation model worth mentioning. First, the model relies on a management approach to classify assets and liabilities in the business and financing sections in a manner that best reflects the way the asset or liability is used within the entity. Second, the Boards have concluded that use of the direct method for the statement of cash flows is more consistent with the objectives of coherency and disaggregation of information. Finally, the proposed presentation model includes a new schedule that reconciles cash flows to comprehensive income. This schedule will be included in the notes to the financial statements. Table 3 illustrates the structure of the schedule:

Table 3: Reconciliation Schedule

\begin{tabular}{|l|l|l|l|l|l|l|}
\hline $\begin{array}{l}\text { Statement of } \\
\text { Cash Flows }\end{array}$ & $\begin{array}{l}\text { Cash } \\
\text { Flows }\end{array}$ & $\begin{array}{l}\text { Accruals, } \\
\text { Allocations } \\
\text { and Other }\end{array}$ & $\begin{array}{l}\text { Recurring } \\
\text { Valuation } \\
\text { Adjustment }\end{array}$ & $\begin{array}{l}\text { All } \\
\text { Other }\end{array}$ & $\begin{array}{l}\text { Comprehensive } \\
\text { Income }\end{array}$ & $\begin{array}{l}\text { Statement of } \\
\text { Comprehensive Income }\end{array}$ \\
\hline $\begin{array}{l}\text { Cash from } \\
\text { wholesale } \\
\text { Customers }\end{array}$ & $1,928,798$ & 662,602 & & $2,991,400$ & Sales-Wholesale \\
\hline $\begin{array}{l}\text { Cash from } \\
\text { retail } \\
\text { customers }\end{array}$ & $\underline{643,275}$ & $\underline{4,575}$ & & $\underline{647,850}$ & Sales-retail \\
\hline $\begin{array}{l}\text { Total cash } \\
\text { from } \\
\text { customers }\end{array}$ & $2,572,073$ & 667,177 & & $3,219,250$ & Total Revenue \\
\hline
\end{tabular}

Note: Adapted from Discussion Paper (Preliminary Views, 2008).

The discussion paper included an invitation for comments on the proposals included in the paper. Twentysix questions were included in the paper. Respondents were asked to respond in writing by April 14, 2009.

\section{THE COMMENT LETTERS}

The IASB/FASB boards received a total of 227 comment letters. The comments were reviewed and summarized by the technical staff. A comment letter summary report was presented for discussion at the IASB/FASB July 14, 2009 meeting.

A summary of the respondents is presented below: 
Table 4: Comment Letter Summary

\begin{tabular}{|l|c|c|c|}
\hline & Total & IFRS & U.S. GAAP \\
\hline Preparers & 98 & 73 & 25 \\
\hline Auditors & 38 & 29 & 9 \\
\hline Users & 24 & 17 & 7 \\
\hline Standard setters/Regulators & 22 & 22 & 0 \\
\hline Academics & 18 & 7 & 11 \\
\hline Others & 27 & 22 & 5 \\
\hline Total & 227 & 170 & 57 \\
\hline
\end{tabular}

Note: Adapted from Comment Letter Summary (2009)

Some of the main points highlighted in the technical staff summary are as follows:

1. Objectives - There was general support for the Boards' objectives of cohesiveness, disaggregation, liquidity, and financial flexibility. However, most respondents took issue with the concept of line-item cohesiveness, and felt that cohesiveness might be more appropriate if applied at a higher level. Some respondents felt that presenting disaggregated information in the notes to financial statements might be more appropriate than on the face of the financial statements. Lastly, many respondents suggested that the proposed financial statement changes were not designed to meet the needs of a broad range of users, but seemed to be designed more for analysts who use financial statement information for valuation purposes.

2. Separation of business activities from financing activities - Most respondents supported the separation of business activities from financing activities, although several respondents pointed out that separation might prove to be difficult in actual practice, suggesting that the distinction might be arbitrary, thereby reducing the information's usefulness.

3. A separate equity section - There was majority support for a separate equity section.

4. A separate discontinued operations section - There was nearly unanimous support for a separate discontinued operations section.

5. Management approach to classification - Respondents' views were mixed on this issue. Respondents who favored the management approach think that classifying assets and liabilities in a manner that reflects their use provides relevant information for financial statement users. Respondents who did not support this approach pointed to reduced comparability among entities.

6. Statement of comprehensive income - Respondents were split on whether an entity should include all components of comprehensive income in a single statement or two separate statements. Respondents who favored the approach pointed to greater transparency, consistency and comparability. Respondents who opposed the single statement approach argued that operating income and net income were the primary focus of most investors, and that the inclusion of other comprehensive items within a single statement might lead to confusion.

7. Direct method statement of cash flows - Two-thirds of the respondents did not agree that the direct method would provide more decision-useful information than the indirect method, and a majority of the respondents did not favor requiring all entities to use only the direct method. Respondents who opposed the direct method claimed that management was not currently using operating cash receipts and payments information to run its business and financial statement users were not asking for it. These respondents also pointed to a complete retooling of their accounting and financial reporting systems, suggesting that the costs of such an endeavor would far outweigh the benefits.

8. Reconciliation schedule - Most respondents did not favor the proposed schedule that reconciles the statement of comprehensive income with the cash flows statement. They thought that 1) the reconciliation schedule was rather long and might be too complex for most financial statement users to grasp, and 2) the cost of preparing the schedule by far outweighed the benefits.

9. Application to nonpublic entities - Although the board had not considered whether the proposed financial statement presentation model should apply to nonpublic companies, respondents were asked for their views on this issue. Respondents' views were mixed. Those that favored inclusion cited two reasons: 1) if the proposed financial statement presentation model proved useful for public entities, then it should prove useful for nonpublic entities, and 2) one presentation model eliminates possible confusion among users. Those who opposed inclusion cited two reasons: 1) the cost doesn't justify the benefit for nonpublic 
companies, and 2) the proposed presentation model might be too complex for small nonpublic companies.

Clearly, the most significant area of concern from the respondents was the mandate requiring companies to use the direct method in presenting the statement of cash flows. Over two-thirds of the respondents (including such companies as McDonald Corporation (Comment Letter \# 120), Intel Corporation (Comment Letter \# 25), Microsoft Corporation (Comment Letter \# 134), and Bayer (Comment Letter \#57)) have raised serious objections, claiming that the cost far outweighs the benefits. Intel's controller estimated that implementation costs for his company would exceed \$5 million, and ongoing costs would approximate \$2 million per year (Comment Letter \#25).

\section{THE STAFF DRAFT OF THE EXPOSURE DRAFT}

On July 1, 2010, the FASB and the IASB posted a draft copy of an exposure draft on financial statement presentation (Staff Draft, 2010). Although similar to the Discussion Paper issued in October 2008, this 151- page document takes on the style and structure of a typical FASB statement, focusing more on the "nuts and bolts" of implementation and less on justification. The basic financial statement presentation model has changed little between the two documents. The significant changes are as follows:

1. The Boards have decided that the proposed financial statement presentation standard should apply to all business entities, public and private.

2. The Boards have dropped the reconciliation statement (reconciling the statement of comprehensive income with the statement of cash flows on a line-by-line basis. Instead, a reconciliation of significant asset and liability accounts will be included in the notes to the financial statements.

Despite the opposition heard from more than two-thirds of the respondents, the Boards have remained steadfast in requiring the companies use the direct method in presenting the statement of cash flows.

The exposure draft of the financial statement presentation model is scheduled for release during $1^{\text {st }}$ quarter of 2011. Given the similarity in scope between the Discussion Paper and the Staff draft, it is reasonable to assume that little will change between the Staff Draft and the final Exposure Draft.

\section{IMPLICATIONS}

The proposed financial statement presentation model has enormous and far- reaching implications. It is worthwhile to examine the implications that the changes are likely to have on the business community, the accounting profession, educators, and investors.

First, there is the cost associated with implementing the new financial statement presentation model. As already mentioned, Intel's controller had estimated implementation costs of more than $\$ 5$ million, with ongoing costs approximating \$2million per year. Even assuming that his estimate is somewhat exaggerated, it is safe to conclude that the cost to Corporate America for retooling its accounting software to accommodate this new financial statement presentation model is enormous. Every accounting system, every software package (both custom and offthe-shelf), and nearly every financial model will require a significant update. Given the increase in financial information, audit fees will undoubtedly rise. Corporate America (and corporate stockholders indirectly) will be paying the bill for the new financial statement presentation model. In terms of winners and losers, the accounting and finance software producers are clear winners, while financial statement preparers (the companies and their stockholders) are the losers.

It only takes a quick perusal of Table 1 and Table 2 to conclude that financial statements and the accompanying notes to the financial statements will be more complex and contain more information. Accounting firms will be the winners, increase their fess to cover the additional work. The financial statement preparers (the companies and their stockholders) are the losers, paying a higher price to the public accounting firms.

Educators should fare nicely as a result of the new financial statement presentation model, especially in the continuing professional education segment. Much of Corporate America has not even seen the proposed financial 
statement presentation model; it may come as quite an initial shock. Educators come across as winners, with potentially plenty to do for a long while. Every accounting and finance book and profession publication will require an update. Book sales should soar. There are no losers here.

Finally, investors and analysts will have a new set of financial statements and notes to analyze, containing substantially more data. For the sophisticated investor and analyst, the new financial statement model should satisfy their seemingly inexhaustible appetite for more data. For the unsophisticated investor, the new financial statement presentation model might give them heartburn. The level of sophistical seems to be the deciding factor as to which investor or analyst is a winner or a loser.

\section{CONCLUSION}

The IASB/FASB boards have spent nearly 10 years on designing a new financial statement presentation model. Having gone through countless meetings and absorbing an enormous amount of commentary from accountants, educators, financial analysts, businessmen and investors, the boards are close to bringing this project to its conclusion.

This project and its implications are too big to escape controversy. The objection by many respondents to elimination of the indirect method approach to the statement of cash flows appears lost for now, but the new financial statement presentation model must go through the exposure draft phase before becoming "cast in stone." Since December 2009, an 18-member panel formed by the AICPA, the Financial Accounting Foundation (the FASB's parent organization), and the National Association of State Boards of Accountancy have been working on models that are based on current U.S. GAAP that would result in different standards for private companies (Private Company Financial Reporting, September 2010). So, as the IASB/FASB financial statement presentation model project turns the corner and heads "into the home stretch," a "relative" group puts forth an effort suggesting that financial standards (including financial statement presentation models) be split into two groups: one for public companies, and one for private companies. What effect the work of this group will have on the IASB/FASB financial statement presentation model is not clear at this time. What is clear is that financial statements, as we know them, are about to change. A working draft of the financial statement presentation model can be viewed on the FASB's website. And although significant changes to the model are still possible, it is now time to start preparing for a new set of financial statements.

\section{AUTHOR INFORMATION}

Dr. Clemense Ehoff Jr., CPA is Assistant Professor of Accounting, Kean University, Union New Jersey. He holds a Ph. D in Business Administration from San Francisco's Golden Gate University. He has more than 30 years professional business experience and has held full-time faculty and adjunct positions at universities predominantly in the Eastern United States. Over the last ten years, Dr. Ehoff has been involved in teaching accounting and tax courses in an online platform. He operates a consulting and tax practice. He has published articles in Elevator World, and other journals.

\section{REFERENCES}

1. DeFelice, A. (2010, September). Blue-Ribbon Panel Narrows Field for Private Company Financial Reporting. Journal of Accountancy, 24-28.

2. Financial Accounting Standards Board (FASB) (2008) Discussion Paper: Preliminary Views on Financial Statement Presentation. Retrieved February 15, 2009 from http://www.fasb.org/cs/ContentServer?c=Document_C\&pagename=FASB\%2FDocument_C\%2FDocument Page\&cid=1175801986226http://www.fasb.org/cs/ContentServer?c=Document_C\&pagename=FASB\%2F Document_C\%2FDocumentPage\&cid=1175801986226.

3. Financial Accounting Standards Board (FASB)(2009) Comment Letters. Retrieved October 12, 2009 from http://www.fasb.org/jsp/FASB/CommentLetter_C/CommentLetterPage\&cid=1218220137090\&project_id= $\underline{1630-100 .}$. 
4. International Accounting Standards Board (IASB), \& Financial Accounting Standards Board (FASB) (2009) Comment Letter Summary presented at the July 14, 2009 Boards meeting. Retrieved August 5, 2010 from http://www.iasb.org/NR/rdonlyres/791DE489-E887-4652-9DD179789C36F032/0/FSP0907b17Cobs.pdf.

5. Financial Accounting Standards Board (FASB)(2010) Staff Draft of an Exposure Draft on Financial Statement Presentation. Retrieved July 20, 2010 from http://www.fasb.org/cs/BlobServer?blobcol=urldata\&blobtable=MungoBlobs\&blobkey=id\&blobwhere=11 75820952978\&blobheader=application\%2Fpdf.

6. $\quad$ Spiceland, D., Sepe, J., \& Nelson, M. (2011). Intermediate Accounting (6 $6^{\text {th }}$ ed.). New York: McGraw-Hill Irwin. 
NOTES 